\title{
Somatostatin receptor subtypes in hormone-refractory (castration-resistant) prostatic carcinoma
}

\author{
Roberta Mazzucchelli ${ }^{1, *}$, Doriana Morichetti ${ }^{1, *}$, Marina Scarpelli ${ }^{1}$, Aldo V Bono ${ }^{1}$, Antonio Lopez-Beltran ${ }^{2}$, \\ Liang Cheng ${ }^{3}$, Ziya Kirkali ${ }^{4}$ and Rodolfo Montironi ${ }^{1}$
}

The aim of this study was to examine the tissue expression and localisation of the somatostatin receptors (SSTRs) in hormone-refractory (HR) prostate cancer (PCa). Five SSTRs were evaluated immunohistochemically in 20 radical prostatectomies (RPs) with Gleason score (GS) $3+3=6 \mathrm{PCa}$, in $20 \mathrm{RPs}$ with GS $4+4=8$ and $4+5=9 \mathrm{PCa}$, and 20 transurethral resection of the prostate specimens with HR PCa. The mean values in the cytoplasm (all five SSTRs were expressed), membrane (only SSTR3 and SSTR4 were expressed) and nuclei (only SSTR4 and SSTR5 were expressed) of the glands in HR PCa were 20-70\% lower than in the other two groups, the differences being statistically significant. All five SSTRs were expressed in the smooth muscle and endothelial cells of HR PCa, the mean values being lower than in the other two groups. In conclusion, this study expands our knowledge on the expression and localisation of five SSTRs in the various tissue components in the HR PCa compared with hormone-sensitive PCa. Asian Journal of Andrology (2011) 13, 242-247; doi:10.1038/aja.2010.100; published online 13 December 2010

Keywords: hormone-refractory prostate cancer; prostate cancer progression; prostatic adenocarcinoma; somatostatin receptors

\section{INTRODUCTION}

Current treatment for localized, early-stage prostate cancer $(\mathrm{PCa})$ involves either surgery (radical prostatectomy (RP)) or radiation, although in some cases active surveillance is appropriate. The standard treatment for patients with hormone-sensitive metastatic disease is to deplete testosterone concentrations with a gonadotropin-releasing hormone analogue and antagonist, or surgical orchiectomy, either alone or in combination with an anti-androgen. The results are predictable: an initial decline in serum prostate-specific antigen (PSA), the secreted protein product of an androgen receptor-regulated gene, followed by tumour regression. After a period of quiescence, PSA concentrations rise, indicating androgen receptor reactivation, followed by disease progression and the development of disease-related symptoms. This phase of the illness represents a transition to hormone-refractory (HR) prostatic adenocarcinoma. The median survival for patients with HR PCa is less than 1 year, and the treatment options available, comprising chemotherapy, are only to be seen as palliative. $^{1}$

Conventional chemotherapy for PCa that is no longer responsive to androgen deprivation was initially found to produce only marginal responses, ${ }^{2}$ but is now being re-evaluated with interest as new agents and better supportive care become available. ${ }^{3}$ Nevertheless, palliation still remains the primary goal of current chemotherapy, and overall response rates are low and associated with general toxicity. To overcome the problem of toxicity, attempts have been made to achieve site-specific drug delivery and improve the therapeutic index. Targeted chemotherapy using potent cytotoxic radicals conjugated to carrier molecules, such as antibodies ${ }^{4,5}$ or analogues of peptide hormones, ${ }^{6}$ which can be specifically recognized by tumour cells, improves the therapy of HR PCa.

Among the analogues of peptide hormones, somatostatin (SST) analogues have gained the most attention because of their antineoplastic effects, such as decreased tumour cell growth and angiogenesis, as well as an increased cancer cell apoptosis. ${ }^{7}$ These inhibitory effects are based on direct and indirect mechanisms. The former are mediated by tumours expressing SST receptors (SSTRs), whereas the latter may play a role in the regulation of SSTR-positive cells by modulating the effect of their growth stimuli, including the inhibition of secretion of growth-promoting factors, such as insulin-like growth factor-1, epidermal growth factor and transforming growth factor, all of which specifically regulate tumour growth. ${ }^{7}$

Previous studies from our group evaluated the five SSTRs in conventional PCa, androgen-dependent PCa with neuroendocrine (NE) differentiation and androgen-dependent PCa following androgen ablation therapy. ${ }^{8-10}$ These investigations pointed out that typing SSTR expression and localisation could be of great relevance in SST analogue-based treatment approaches. No information is available in the current literature on SSTR subtype expression and localisation in HR PCa.

The aim of the current study was to examine immunohistochemically the expression and localisation of the five SSTRs in HR PCa.

\footnotetext{
${ }^{1}$ Section of Pathological Anatomy, Polytechnic University of the Marche Region, School of Medicine, United Hospitals, Ancona 60126, Italy; ${ }^{2}$ Department of Pathology, Reina Sofia University Hospital and Faculty of Medicine, Cordoba 14001, Spain; ${ }^{3}$ Department of Pathology and Laboratory Medicine, Indiana University School of Medicine, Indianapolis, IN 46202, USA and ${ }^{4}$ Department of Urology, School of Medicine, Dokuz Eylül University, Izmir 35010, Turkey

* These authors contributed equally to this work.

Correspondence: Dr R Montironi (r.montironi@univpm.it)

Received: 26 May 2010; Revised: 5 July 2010; Accepted: 30 July 2010; Published online: 13 December 2010
} 


\section{MATERIALS AND METHODS}

All 60 specimens were obtained from the Pathology Services associated with the United Hospitals-Polytechnic University of the Marche Region, Ancona, Italy. The specimens represented three groups of patients, whose characteristics are shown in Table 1. The procedure for this research project conforms to the provisions of the Declaration of Helsinki:

- Group 1. In total, 20 RPs with androgen-dependent pT2a and Gleason score (GS) $3+3=6$ acinar PCa (name given to this group: RP 3, where 3 indicates that Gleason pattern 3 was analysed).

- Group 2. In total, 20 RPs with androgen-dependent pT2a and GS $4+4=8$ and $4+5=9$ acinar PCa (Table 1$)(\mathrm{RP} 4 / 5$, where 4 and 5 indicate that Gleason patterns 4 and 5 were analysed).

The patients of these first two groups were hormonally untreated. The specimens were formalin fixed for $24 \mathrm{~h}$. The whole-mount technique with complete sampling was used to process the RPs, which were then examined histologically as 5 - $\mu \mathrm{m}$-thick haematoxylin and eosinstained sections. The samples selected for the immunohistochemical analysis were all from the peripheral zone of the prostate to avoid the possibility of the evaluations of the five SSTRs being influenced by their zonal distribution.

- Group 3. In total, 20 transurethral resection of the prostate (TURP) specimens with locally recurrent HR PCa. The material was fixed in formalin for $24 \mathrm{~h}$. HR was defined as at least two consecutive rises in total serum PSA, obtained at least 2 weeks apart, in the presence of castrate levels of testosterone (TURP HR). None of the cases of this group showed NE differentiation, other than a few scattered chromogranin A-positive cells. The initial diagnosis of PCa was done in all 20 TURP specimens (GS: 4-8; median: 6). The patients, all with locally advanced $\mathrm{PCa}$, were treated with external radiation therapy, followed by total androgen blockade until the diagnosis of HR PCa was made. The mean time elapsed from PCa diagnosis to development of HR PCa was 5 years (range: 3-7 years). SSTR

Table 1 The patients' characteristics

\begin{tabular}{|c|c|c|c|}
\hline Variable & $R P 3$ & $R P 4 / 5$ & TURP HR \\
\hline No. of patients & 20 & 20 & 20 \\
\hline $\begin{array}{l}\text { Age (mean, range) } \\
\text { (years) }\end{array}$ & $70(56-84)$ & $69(47-72)$ & 77 (59-85) \\
\hline $\begin{array}{l}\text { Serum PSA (mean, } \\
\text { range) (ng ml }{ }^{-1} \text { ) }\end{array}$ & $2.1(0.1-3.4)$ & $3.4(0.4-5.9)$ & $9.5(3.1-13.4)$ \\
\hline Type of specimens & RP & RP & TURP \\
\hline Cancer features & $\begin{array}{c}\text { pT2a, GS } 6 \\
(3+3)\end{array}$ & $\begin{array}{l}\text { pT2a, GS } 8(4+4) \text { in } 17 \\
\text { patients and GS } 9 \\
(4+5) \text { in } 3 \text { patients }\end{array}$ & rcT4 N1 M1 \\
\hline
\end{tabular}

Abbreviations: GS, Gleason score; PSA, prostate-specific antigen; RP, radical prostatectomy; TURP HR, transurethral resection of the prostate hormone-refractory prostate cancer. evaluation was also done in five of 20 TURP specimens utilized for the initial diagnosis of PCa.

\section{Immunohistochemical staining}

Antibody against SSTR subtypes. For immunohistochemistry, all rabbit polyclonal anti-SSTR subtype antibodies were commercially obtained from Chemicon International Inc. (Temecula, CA, USA). Dilution of the antibodies used is shown in Table 2. Positive control experiments included normal human pancreas and/or anterior pituitary gland obtained from surgery and autopsy, respectively. Negative controls were used for the tested antibodies; the primary antibody was replaced by rabbit non-immune serum.

Immunohistochemistry. In total, $10 \%$ formalin-fixed, paraffinembedded tissue blocks were serially cut into 5 - $\mu \mathrm{m}$-thick sections, which were mounted on silane-coated slides. The sections were then dewaxed in xylene and rehydrated through a graded series of ethanol. Antigen retrieval was done by microwave treatment for 20 min at $98^{\circ} \mathrm{C}$ using $0.01 \mathrm{~mol} \mathrm{l}^{-1}$ citric acid buffer, $\mathrm{pH}$ 6.0. Endogenous peroxidase activity was quenched by incubating the sections in 3\% hydrogen peroxide for $10 \mathrm{~min}$ at room temperature. Non-specific binding sites were blocked through pre-incubation with $1 \%$ bovine albumin in phosphate-buffered saline for $20 \mathrm{~min}$ at room temperature. Reacted tissue sections were then incubated with the antibodies for each SSTR subtype for $18 \mathrm{~h}$ at $4{ }^{\circ} \mathrm{C}$. The antigen-antibody complex was subsequently visualized using the Envision Detection System Kit peroxidase/3,3' -diaminobenzidine (Dako, Glustrop, Denmark) and counterstained with haematoxylin (Figure 1).

Evaluation of immunohistochemistry and statistics. At least 1000 cells were counted by one of us (DM) in contiguous $\times 400$ microscopic fields in each case, separately for the secretory epithelium of $\mathrm{PCa}$ (in all three groups) and for the normal secretory epithelium (Nep) (in groups 1 and 2): smooth muscle cells of the stroma and endothelial cells. Smooth muscle and endothelial cells were measured in areas approximately $1 \mathrm{~mm}$ away from PCa. The Nep was $5 \mathrm{~mm}$ away from PCa. Immunostaining was evaluated for the following three cell components: cytoplasm, cell membrane and nucleus. Staining intensity was graded as $0,1+, 2+$ and $3+$. In each case, the percentages of positive cells and of cells with strong intensity (that is, $2+$ and $3+$ ) were evaluated. For each group, the mean and standard deviation were then calculated. The differences between the groups were considered statistically significant at a value of $P<0.05$ (Mann-Whitney test, SPSS software; SPSS Inc., Chicago, IL, USA).

\section{Assessment of antibody specificity}

The specificity of the five rabbit polyclonal anti-SSTR antibodies used in this study was shown in a previous investigation with a Western blot technique. $^{11}$

Table 2 Characteristics of the polyclonal antibodies used in immunohistochemistry

\begin{tabular}{|c|c|c|c|c|}
\hline Antibody & Type & Immunogen ${ }^{a}$ (synthetic peptide form) & Dilution & Source \\
\hline SSTR1 & Rabbit & C-terminal domain of human SSTR1 & $1 / 300$ & Chemicon International Inc., Temecula, CA, USA \\
\hline SSTR2 & Rabbit & Second extracellular domain of human SSTR2 & $1 / 100$ & Chemicon International Inc. \\
\hline SSTR3 & Rabbit & C-terminal domain of human SSTR3 & $1 / 300$ & Chemicon International Inc. \\
\hline SSTR4 & Rabbit & N-terminal extracellular domain of human SSTR4 & $1 / 400$ & Chemicon International Inc. \\
\hline SSTR5 & Rabbit & C-terminal domain of human SSTR5 & $1 / 200$ & Chemicon International Inc. \\
\hline 'Visualisation System' & ENVISION & - & Ready-to-use & Dako, Glustrop, Denmark \\
\hline
\end{tabular}

Abbreviation: SSTR, somatostatin receptor.

a From the manufacturer's data sheet. 


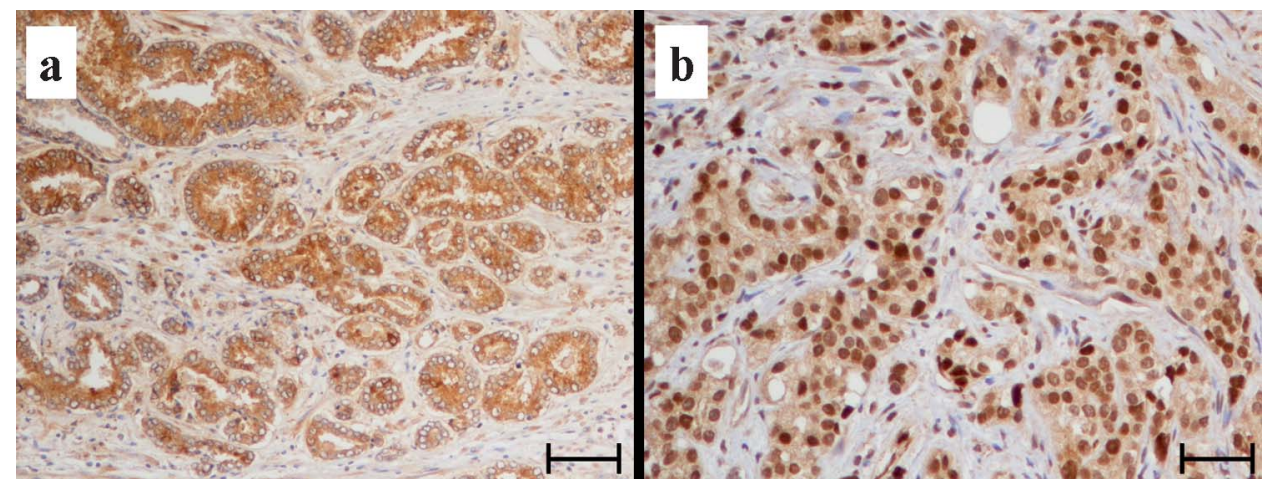

Figure 1 Immunostaining for the SSTR4: (a) untreated prostate cancer; (b) hormone-refractory prostate cancer. SSTR, somatostatin receptor. Bars=100 $\mu$ m.

\section{RESULTS}

SSTRs in groups 1 (RP 3) and 2 (RP 4/5)

Tables 3 and 4 report the percentages of positive cells for Nep and PCa in the three groups, separately, for the epithelial cell membrane, cytoplasmic and nuclear locations, and for smooth muscle and endothelial cells. These tables also report the percentages of intensely stained cells.

The values in the epithelial, smooth muscle and endothelial cells in Nep and PCa, including statistics, were included in a previous study ${ }^{8,9}$ and are used in the current investigation as reference in the evaluation of SSTRs in the HR group.
Briefly, in the epithelial cells, cytoplasmic staining was seen for all five SSTRs, the mean percentages of positive cells in Nep and PCa of the RP 3 and RP 4/5 groups being similar. Cell membrane staining was seen for SSTR3 and SSTR4, of which the mean percentages of positive cells, higher in SSTR3 than in SSTR4, decreased sharply in PCa compared with Nep. Nuclear staining was seen with SSTR4 and SSTR5 in the cancer groups; the mean percentages for the former were slightly higher than those for the latter (Table 3). The differences were statistically significant for some of the comparisons (data not shown), ${ }^{8,9}$ SSTR subtype expression and localisation in the cancer areas in the

Table 3 Percentages of secretory cells with positive cytoplasmic, membrane and nuclear staining (the values in parentheses are those with strong intensity, that is, with $2+$ and $3+$ )

\begin{tabular}{|c|c|c|c|c|c|}
\hline \multirow{2}{*}{ SSTRS } & \multicolumn{2}{|c|}{$\mathrm{Nep}$} & \multicolumn{3}{|c|}{$\mathrm{PCa}$} \\
\hline & $R P 3$ & $R P 4 / 5$ & $R P 3$ & $R P 4 / 5$ & TURP HR \\
\hline \multicolumn{6}{|l|}{ Cytoplasm } \\
\hline Subtype 2 & $81.2 \pm 14.5(6.0 \pm 4.0)$ & $83.1 \pm 7.3(6.4 \pm 3.4)$ & $83.8 \pm 9.2(10.2 \pm 4.7)$ & $93.7 \pm 6.8(11.7 \pm 4.9)$ & $66.3 \pm 14(9.0 \pm 4.3)$ \\
\hline Subtype 3 & $81.9 \pm 10.2(8.1 \pm 6.1)$ & $82.6 \pm 4.5(7.5 \pm 1.7)$ & $83.2 \pm 14.9(10.5 \pm 7.4)$ & $87 \pm 24.1(10.1 \pm 3.7)$ & $61.7 \pm 22.8(4.6 \pm 6.1)$ \\
\hline Subtype 4 & $84.3 \pm 9.7(5.1 \pm 2.9)$ & $86.2 \pm 3.2(5.5 \pm 3.7)$ & $86.7 \pm 9.9(13.9 \pm 13.8)$ & $96.1 \pm 5.5(15.2 \pm 7.8)$ & $50.5 \pm 19.6(0 \pm 0)$ \\
\hline Subtype 3 & $54.1 \pm 22.5(13.8 \pm 8.6)$ & $54.9 \pm 11.1(12.8 \pm 6.6)$ & $6.3 \pm 9.3(0.2 \pm 0.4)$ & $8.5 \pm 4.0(0.4 \pm 0.8)$ & $3.5 \pm 4.3(0 \pm 0)$ \\
\hline Subtype 4 & $9.2 \pm 11.3(0.2 \pm 0.4)$ & $9.9 \pm 9.9(0.3 \pm 0.6)$ & $5.8 \pm 3.5(0 \pm 0)$ & $8.2 \pm 0.6(0 \pm 0)$ & $6.7 \pm 1.5(0 \pm 0)$ \\
\hline \multicolumn{6}{|l|}{ Nuclear ${ }^{\mathrm{b}}$} \\
\hline Subtype 4 & $20.2 \pm 8.8(0 \pm 0)$ & $21.8 \pm 15.2(0 \pm 0)$ & $33.7 \pm 25.1(0 \pm 0)$ & $35.3 \pm 16.5(0.3 \pm 0.9)$ & $37.1 \pm 16.2(0 \pm 0)$ \\
\hline Subtype 5 & $45.4 \pm 7.4(0 \pm 0)$ & $47.2 \pm 22.1(0 \pm 0)$ & $26.8 \pm 15.3(0 \pm 0)$ & $32.5 \pm 20.0(1.0 \pm 2.1)$ & $19.5 \pm 16.1(0 \pm 0)$ \\
\hline
\end{tabular}

Abbreviations: Nep, normal epithelium; PCa, prostate cancer; RP, radical prostatectomy; SSTR, somatostatin receptors; TURP HR, transurethral resection of the prostate hormone-refractory prostate cancer.

Values are shown as mean \pm s.d.

ammunohistochemistry for subtypes 1,2 and 5 was negative.

${ }^{\mathrm{b}}$ Immunohistochemistry for subtypes 1,2 and 3 was negative.

Table 4 Percentages of smooth muscle and endothelial cells with positive cytoplasmic staining (the values in brackets are those with strong intensity, that is, with $2+$ and $3+$ )

\begin{tabular}{|c|c|c|c|c|c|c|}
\hline \multirow{2}{*}{ SSTRS } & \multicolumn{3}{|c|}{ Smooth muscle cells } & \multicolumn{3}{|c|}{ Endothelial cells } \\
\hline & $R P 3$ & $R P 4 / 5$ & TURP HR & $R P 3$ & $R P 4 / 5$ & TURP HR \\
\hline Subtype 1 & $91.7 \pm 8.5(57.5 \pm 35.5)$ & $90.9 \pm 9.4(57.6 \pm 24.8)$ & $80.0 \pm 24.3(49.5 \pm 28.3)$ & $99.6 \pm 1.2(58.3 \pm 2.4)$ & $99.0 \pm 3.1(47.2 \pm 4.2)$ & $98.9 \pm 3.1(45.4 \pm 5.7)$ \\
\hline Subtype 2 & $56.0 \pm 20.0(7.0 \pm 3.9)$ & $55.8 \pm 27.5(4.8 \pm 3.5)$ & $54.2 \pm 10.9(3.7 \pm 8.7)$ & $30.2 \pm 10.1(7.8 \pm 4.0)$ & $32.8 \pm 7.5(7.4 \pm 3.3)$ & $29.7 \pm 8.2(5.8 \pm 5.0)$ \\
\hline Subtype 3 & $67.0 \pm 19.3(5.2 \pm 4.1)$ & $67.1 \pm 25.5(4.8 \pm 3.3)$ & $49.9 \pm 21.2(3.4 \pm 5.7)$ & $59.0 \pm 17.8(6.9 \pm 4.8)$ & $59.8 \pm 23.4(6.4 \pm 6.1)$ & $58.5 \pm 19.4(6.3 \pm 7.6)$ \\
\hline Subtype 4 & $56.9 \pm 23.2(3.4 \pm 2.1)$ & $57.0 \pm 6.4(3.3 \pm 2.7)$ & $41.7 \pm 24.5(0 \pm 0)$ & $61.3 \pm 13.9(4.8 \pm 1.5)$ & $61.1 \pm 12.9(4.1 \pm 2.8)$ & $44.1 \pm 16.8(3.1 \pm 1.8)$ \\
\hline Subtype 5 & $22.3 \pm 15.6(0.8 \pm 0.6)$ & $23.4 \pm 20.3(1.1 \pm 1.5)$ & $19.9 \pm 9.4(0 \pm 0)$ & $21.3 \pm 16.2(0.3 \pm 0.7)$ & $21.0 \pm 14.0(0.5 \pm 1.5)$ & $18.8 \pm 5.3(0.4 \pm 1.2)$ \\
\hline
\end{tabular}

Abbreviations: RP, radical prostatectomy; SSTR, somatostatin receptors; TURP HR, transurethral resection of the prostate hormone-refractory prostate cancer. 
RP 4/5 were slightly greater than in the RP 3 , the differences between Gleason 4 and 5 areas being not significant. ${ }^{8,9}$

SSTR staining in the smooth muscle and endothelial cells was seen only in the cytoplasm, the pattern being similar between the two locations and the highest mean values being for SSTR1 and the lowest for SSTR5 (Table 4).

\section{SSTR in group 3 (TURP HR)}

The mean values of SSTR expression in the cytoplasm, cell membrane and nuclei of the epithelial cells of HR PCa were $20-70 \%$ lower than in the cancer areas of the PCa of the other two groups (Table 3 ).

When considering cytoplasm staining, the differences between the RP 3 and HR groups were statistically significant for all SSTRs, the $P$ values ranging from 0.023 for SSTR 3 to $<0.001$ for SSTR 4 and SSTR5. Statistically significant differences were also present in the comparison between RP $4 / 5$ and HR groups, the $P$ values ranging from 0.002 for SSTR3 to $<0.001$ for the other SSTRs.

Membrane staining was observed for SSTR3 and SSTR4. The mean percentage of the former was lower than in the other two PCa groups, the differences being statistically significant in comparison with RP 4/5 $(P=0.019)$. The mean value for the latter was intermediate between those of the two cancer groups, the differences being not statistically significant.

Nuclear staining was seen for SSTR4 and SSTR5. The mean percentage of the former was higher than those in the other two cancer groups, the differences being not statistically significant. The mean value for SSTR5 was lower than those of the other two cancer groups, the differences being statistically significant (TURP HR versus RP 3 , $P=0.015$; TURP HR versus RP $4 / 5, P=0.007$ ).

All five SSTRs were expressed in the smooth muscle and endothelial cells, the mean values being lower than in the other two groups. For instance, SSTR4 expression was 40\% lower in the smooth muscle cells (TURP HR versus RP 3, $P=0.002$; TURP HR versus RP 4/5, $P=0.001$ ) and 30\% lower in the endothelial cells (TURP HR versus RP 3, $P=0.003$; HR versus $\mathrm{RP} 4 / 5, P=0.003$ ).

The results obtained in Nep and PCa in the five TURP specimens in which the initial diagnosis of $\mathrm{PCa}$ was made were comparable to those seen in the untreated groups 1 and 2. Chromogranin A immunohistochemistry was done in deeper sections in two TURP specimens, with 3+ cytoplasmic staining for the SSTR4 in the epithelium. Some, but not all, of the cells present in the same location were also chromogranin A-positive.

\section{DISCUSSION}

SST is a 14- or 28-amino-acid peptide that was originally described in 1973 as a hypothalamic NE hormone, ${ }^{12}$ the role of which was to inhibit the secretion of growth hormone from the anterior pituitary gland. The presence of this peptide hormone was subsequently detected throughout the central and peripheral nervous systems, and in several organs, including the prostate. The actions of SST are mediated by a family of transmembrane domain G-protein-coupled receptors that comprise five distinct subtypes and that share common signalling pathways. ${ }^{13}$ Although SSTRs are membrane-associated receptors, a significant amount of staining is seen within the cytoplasm and some nuclear staining is also present in many immunoreactive cells. ${ }^{11}$ The interpretation is that, after binding their ligand, SSTR-ligand complexes undergo cellular internalisation with progressive intracytoplasmic and intranuclear translocation.

SSTRs are widely expressed in many organs, ${ }^{14-18}$ including the prostate, ${ }^{19,20}$ in the normal tissue, as well as in benign and malignant lesions, at the level of epithelial, stromal smooth muscle and endothelial cells. Frequently multiple subtypes coexist in the same cell. The SSTRs present in the epithelial cells mediate the antiproliferative effect of SST. A possible role of the SSTRs in the smooth muscle could be to influence the release of various growth factors known to be synthesized in the stroma. As several of these growth factors act in a paracrine manner on the glandular part of the prostate to regulate prostate growth, ${ }^{7}$ SST could indirectly regulate biological events in the prostatic gland through a stromal action. The precise roles of the SSTRs in endothelial cells have not yet been clarified, but SST may be involved in angiogenesis.

Cloning of five SSTRs has led to the development of subtype-selective agonists. The antiproliferative and antiangiogenic properties of SST analogues have been exploited in several clinical trials. ${ }^{13,21}$ Therefore, it is very important to determine cell expression and localisation of the five SSTRs. SSTR profiling in individual patients may be of relevance to better tailor the SST analogue-based diagnosis and treatment.

Detailed information on the expression and localisation of the five SSTR subtypes in epithelial cells in normal prostate, HGPIN and PCa, including cancers with NE differentiation, as well as in the smooth muscle and endothelial cells from hormonally untreated and treated prostates, has been reported in a number of studies ${ }^{7-10,12,19,20,22-24}$ (Table 5). The current literature contains only very few experimental and clinical reports on the SSTR expression in HR PCa, pointing out only their relevance in SST analogue-based diagnostic and treatment approaches. ${ }^{25-29}$ However, none of them fully investigated all five SSTRs.

The present study investigates the expression and localisation of the five SSTRs in the epithelial, stromal smooth muscle and blood vessel endothelial cells by investigating HR PCa. The main findings are represented by the fact that SSTR4 was the only receptor to be simultaneously present in the membrane, where the mean percentage was greater than in RP 3, in the cytoplasm, where it was lower than in RP 3 and RP 4/5, as well as in the nucleus, where it was higher than in the other two groups. Their expression and localisation are unchanged in the smooth muscle and endothelial cells in comparison with hormone-sensitive PCa.

The current literature contains only very few experimental and clinical reports on the SSTR expression in HR PCa, pointing out only their relevance in SST analogue-based diagnostic and treatment approaches. ${ }^{25-29}$ However, none of them fully investigated all five SSTRs. Our study is the first to fully document the pattern of SSTR expression and localisation in HR PCa in tissue sections and therefore greatly expand our current knowledge in this field.

The limitation of our study is that immunohistochemistry was not associated with a molecular investigation. This type of comparative study was done to some extent by others, including Hansson et al. ${ }^{19}$ in human benign prostatic hyperplasia and prostatic cancer, and Klisovic et al. $^{30}$ in human ocular tissue. The former group investigated SSTR2 and SSTR4 only. The latter investigated SSTR1 and SSTR2 in particular. Both groups found good correlation between immunohistochemical distribution of SSTRs and their gene expression.

Our study is the first to fully document the pattern of expression and localisation of all five SSTRs in HR PCa in tissue sections and complements the type of information obtained in our previous studies on PCa with NE differentiation and in androgen-ablated PCa. Typing SSTR expression in HR PCa could be of relevance to target SST analogue-based diagnostic approach and treatment. Examination of a large cohort of patient specimens will give better insight into the relevance and significance of SSTRs in clinical use. 
Table 5 Studies on the expression and localisation of the SSTRs in human prostate tissue

\begin{tabular}{|c|c|c|c|c|c|}
\hline Authors and reference & Year & Technique & Receptors & Localisation & Type of tissue \\
\hline Reubi et al. ${ }^{20}$ & 1995 & $\begin{array}{l}\text { Autoradiography, in situ } \\
\text { hybridisation }\end{array}$ & $\begin{array}{l}\text { SSTR1 } \\
\text { SSTR2 } \\
\text { SSTR3 }\end{array}$ & Smooth muscle, endothelium & $\mathrm{BPH}$ and $\mathrm{PCa}$ \\
\hline Dizeyi et al. ${ }^{7}$ & 2002 & IHC, RT-PCR, Western blot & $\begin{array}{l}\text { SSTR1 } \\
\text { SSTR2 } \\
\text { SSTR3 } \\
\text { SSTR4 } \\
\text { SSTR5 }\end{array}$ & $\begin{array}{l}\text { Epithelial cells, stromal cells, } \\
\text { endothelium }\end{array}$ & Normal, BPH, PCa \\
\hline Hansson et al. ${ }^{19}$ & 2002 & In situ hybridisation & $\begin{array}{l}\text { SSTR2 } \\
\text { SSTR4 }\end{array}$ & Epithelial cells, stromal cells & BPH PIN, PCa \\
\hline Volante et al. ${ }^{24}$ & 2007 & $\mathrm{IHC}$ & $\begin{array}{l}\text { SSTR2A } \\
\text { SSTR3 } \\
\text { SSTR5 }\end{array}$ & Epithelial cells & Cancer \\
\hline Cariaga-Martinez et al..$^{22}$ & 2009 & $\mathrm{IHC}$ & SSTR2 & Luminal side of duct and acinar cells & Normal, BPH and PCa \\
\hline Morichetti et al. ${ }^{10}$ & 2010 & $\mathrm{IHC}$ & $\begin{array}{l}\text { SSTR1 } \\
\text { SSTR2 } \\
\text { SSTR3 } \\
\text { SSTR4 } \\
\text { SSTR5 }\end{array}$ & $\begin{array}{l}\text { Secretory cells, basal cells, } \\
\text { smooth muscle stromal cells, } \\
\text { endothelial cells }\end{array}$ & Normal, HGPIN and incidental PCa \\
\hline Morichetti et al. ${ }^{9}$ & 2010 & $\mathrm{IHC}$ & $\begin{array}{l}\text { SSTR1 } \\
\text { SSTR2 } \\
\text { SSTR3 } \\
\text { SSTR4 } \\
\text { SSTR5 }\end{array}$ & $\begin{array}{l}\text { Secretory cells, basal cells, } \\
\text { smooth muscle stromal cells, } \\
\text { endothelial cells }\end{array}$ & PCa with NE differentiation \\
\hline
\end{tabular}

Abbreviations: BPH, benign prostatic hyperplasia; HGPIN, high grade prostatic intraepithelial neoplasia; IHC, immunohistochemistry; NE, neurendocrine; PCa, prostate cancer; PIN, prostatic intraepithelial neoplasia; RT-PCR, real-time polymerase chain reaction; SSTR, somatostatin receptors.

\section{AUTHOR CONTRIBUTIONS}

AVB developed the concept and designed the study. RM and DM conducted data acquisition. MS and ALB analysed and interpreted the data. LC drafted the manuscript. ZK and RM supervised the project.

\section{COMPETING FINANCIAL INTERESTS}

The authors declare no conflict financial interests.

\section{ACKNOWLEDGMENTS}

This study was supported by a grant from Novartis Oncology, Italy. We gratefully acknowledge the support given by Dr Alfredo Santinelli in the statistical analysis.

1 Plonowski A, Schally AV, Nagy A, Sun B, Szepeshazi K. Inhibition of PC-3 human androgen-independent prostate cancer and its metastases by cytotoxic somatostatin analogue AN-238. Cancer Res 1999; 59: 1947-53.
2 Yagoda A, Petrylak D. Cytotoxic chemotherapy for advanced hormone-resistant prostate cancer. Cancer 1993; 71: 1098-109.

3 Oh WK, Kantoff PW. Management of hormone refractory prostate cancer: current standards and future prospects. J Urol 1998; 160: 1220-9.

4 Sivam GP, Martin PJ, Reisfeld RA, Mueller BM. Therapeutic efficacy of a doxorubicin immunoconjugate in a preclinical model of spontaneous metastatic human melanoma. Cancer Res 1995; 55: 2352-6.

5 Yeh MY, Roffler SR, Yu MH. Doxorubicin: monoclonal antibody conjugate for therapy of human cervical carcinoma. Int J Cancer 1992; 51: 274-82.

6 Schally AV, Nagy A. Chemotherapy targeted to cancers through tumoral hormone receptors. Trends Endocrinol Metab 2004; 15: 300-10.

7 Dizeyi N, Konrad L, Bjartell A, Wu H, Gadaleanu V et al. Localization and mRNA expression of somatostatin receptor subtypes in human prostatic tissue and prostate cancer cell lines. Urol Oncol 2002; 7: 91-8.

8 Mazzucchelli R, Morichetti D, Santinelli A, Scarpelli M, Bono AV et al. Immunohistochemical expression and localization of somatostatin receptor subtypes in prostate cancer following complete androgen ablation. Anal Cell Pathol (Amst) 2010; 33: 27-36; doi: 10.3233/CLO-2008-0433.

9 Morichetti D, Mazzucchelli R, Santinelli A, Stramazzotti D, Lopez-Beltran A et al. Immunohistochemical expression and localization of somatostatin receptor subtypes in prostate cancer with neuroendocrine differentiation. Int $J$ Immunopathol Pharmacol 2010; 23: 511-22. 
10 Morichetti D, Mazzucchelli R, Stramazzotti D, Santinelli A, Lopez-Beltran A et al. Immunohistochemical expression of somatostatin receptor subtypes in prostate tissue from cystoprostatectomies with incidental prostate cancer. BJU Int; e-pub ahead of print 1 May 2010; 106: 1072-80.

11 Montironi R, Cheng L, Mazzucchelli R, Morichetti D, Stramazzotti D et al. Immunohistochemical detection and localization of somatostatin receptor subtypes in prostate tissue from patients with bladder outlet obstruction. Cell Oncol 2008; 30: 473-82.

12 Brazeau P, Vale W, Burgus R, Ling N, Butcher M et al. Hypothalamic polypeptide that inhibits the secretion of immunoreactive pituitary growth hormone. Science 1973; 179: 77-9.

13 Bousquet C, Guillermet J, Vernejoul F, Lahlou H, Buscail L et al. Somatostatin receptors and regulation of cell proliferation. Dig Liver Dis 2004; 36 Suppl 1: S2-7.

14 Balster AD, O'Dorisio MS, Summers MA, Turman MA. Segmental expression of somatostatin receptor subtypes sst $_{1}$ and sst $_{2}$ in tubules and glomeruli of human kidney. Am J Physiol Renal Physiol 2001; 280: 457-65.

15 Casini Raggi C, Calabrò A, Renzi D, Briganti V, Cianchi F et al. Quantitative evaluation of somatostatin receptor subtype 2 expression in sporadic colorectal tumor and in the corresponding normal mucosa. Clin Cancer Res 2002; 8: 419-27.

16 Portela-Gomes MG, Stridsberg M, Grimelius L, Oberg K, Janson ET. Expression of the five different somatostatin receptor subtypes in endocrine cells of the pancreas. Appl Immunohistochem Mol Morphol 2002; 8: 126-32.

17 Reynaert H, Rombouts K, Vandermonde A, Urbain D, Kumar U et al. Expression of somatostatin receptors in normal and cirrhotic human liver and in hepatocellular carcinoma. Gut 2004; 53: 1180-9.

18 Zatelli MC, degli Uberti EC. Somatostatin receptors: from basic science to clinical approach—thyroid. Dig Liver Dis 2004; 36: 86-92.

19 Hansson J, Bjartell A, Gadaleanu V, Dizeyi N, Abrahamsson PA. Expression of somatostatin receptor subtypes 2 and 4 in human benign prostatic hyperplasia and prostatic cancer. Prostate 2002; 53: 50-9.

20 Reubi JC, Waser B, Schaer JC, Markwalder R. Somatostatin receptors in human prostate and prostate cancer. J Clin Endocrinol Metab 1995; 80: 2806-14.

21 Verset G, Verslype C, Reynaert H, Borbath I, Langlet P et al. Efficacy of the combination of long-acting release octreotide and tamoxifen in patients with advanced hepatocellular carcinoma: a randomised multicentre phase III study. $\mathrm{Br} \mathrm{J}$ Cancer 2007; 97: 582-8.

22 Cariaga-Martinez AE, Lorenzati MA, Riera MA, Cubilla MA, de la Rossa A et al. Tumora prostate shows different expression pattern of somatostatin receptor 2 (SSTR2) and phosphotyrosine phosphatase SHP-1 (PTPN6) according to tumor progression. Adv Urol; e-pub ahead of print 12 April 2009; doi: 10.1155/2009/723831.

23 Halmos G, Schally AV, Sun B, Davis R, Bostwick DG et al. High expression of somatostatin receptors and messenger ribonucleic acid for its receptor subtypes in organ-confined and locally advanced human prostate cancers. J Clin Endocrinol Metab 2000; 85: 2564-71

24 Volante M, Brizzi MP, Faggiano A, La Rosa S, Rapa I et al. Somatostatin receptor type $2 \mathrm{~A}$ immunohistochemistry in neuroendocrine tumors: a proposal of a scoring system correlated with somatostatin receptor scintigraphy. Mod Pathol 2007; 20: 1172-82.

25 Letsch M, Schally AV, Szepeshazi K, Halmos G, Nagy A. Effective treatment of experimental androgen sensitive and androgen independent intraosseous prostate cancer with targeted cytotoxic somatostatin analogue AN-238. J Urol 2004; 171 911-5.

26 Nilsson S, Reubi JC, Kalkner KM, Laissue JA, Horisberger U et al. Metastatic hormone-refractory prostatic adenocarcinoma expresses somatostatin receptors and is visualized in vivo by [ ${ }^{111} \mathrm{In}$-labeled DTPA-D-[Phe ${ }^{1}$ ]-octreotide scintigraphy. Cancer Res 1995; 55: 5805s-10s.

27 Mencoboni M, Tredici S, Rebella L, Bergaglio M, Galbusera V et al. Effect of chemotherapy on somatostatin receptor detection with octreotide scintigraphy in hormone-refractory prostate cancer patients. Anticancer Res 2006; 26: 2233-5.

28 Koppan M, Nagy A, Schally AV, Arencibia JM, Plonowski A et al. Targeted cytotoxic analogue of somatostatin $\mathrm{AN}-238$ inhibits growth of androgen-independent Dunning R-3327-AT-1 prostate cancer in rats at nontoxic doses. Cancer Res 1998; 58: 41327 .

29 Koutsilieris M, Bogdanos J, Milathianakis C, Dimopoulos P, Dimopoulos T et al. Combination therapy using LHRH and somatostatin analogues plus dexamethasone in androgen ablation refractory prostate cancer patients with bone involvement: a bench to bedside approach. Expert Opin Investig Drugs 2006; 15: 795-804.

30 Klisovic DD, O'Dorisio MS, Katz SE, Sall JW, Balster D et al. Somatostatin recepto gene expression in human ocular tissues: RT-PCR and immunohistochemical study. Invest Ophthalmol Vis Sci 2001; 42: 2193-201. 